\title{
INVERSI DATA GEOLISTRIK MENGGUNAKAN PARTICLE SWARM OPTIMIZATION: STUDI KASUS DESA GAYAU
}

\section{GEOELECTRICAL DATA INVERSION USING}

\section{PARTICLE SWARM OPTIMIZATION: CASE STUDY OF}

\section{GAYAU VILLAGE}

\author{
Alhada Farduwin ${ }^{1 *}$, Risky Martin Antosia ${ }^{2}$, Intan Andriani Putri ${ }^{3}$, Nono Agus Santoso ${ }^{4}$, Selvi \\ Misnia Irawati ${ }^{5}$ \\ 1,2,3,4,5Program Studi Teknik Geofisika, Jurusan Teknologi Produksi dan Industri, Institut Teknologi \\ Sumatera
}

Received: 2020, N ovember $18^{\text {th }}$ Accepted: 2021, April $1^{\text {st }}$

\author{
Keyword: \\ Aquifer; \\ Gayau; \\ Particle Swarm Optimiza- \\ tion (PSO); \\ VES.
}

\section{Corespondent Email:}

alhada.farduwin@tg.itera.ac.id

\section{How to cite this article:}

Farduwin A., Antosia R.M ., Putri I.A., Santoso N .A., \& Irawati S.M., (2021). Inversi Data VES M enggunakan Algoritma Pso Dalam Penentuan Lapisan Air Tanah: Studi Kasus Desa

\begin{abstract}
Abstrak. Desa Gayau yang terletak di Kecamatan Padang Cermin, Kabupaten Pesawaran sering mengalami kekeringan air pada saat musim kemarau sehingga perlu dilakukannya pengukuran geolistrik untuk mengidentifikasi keberadaan lapisan akuifer air tanah. Pada penelitian ini konfigurasi yang digunakan adalah Schlumberger dengan panjang bentangan $M N / 2$ sebesar $1,5,10$, dan 20 meter. Sedangkan panjang bentangan $A B / 2$ sebesar 6 hingga 300 meter. Pada tahapan inversi data VES, kami menggunakan algoritma Particle Swarm Optimization (PSO) untuk memperoleh nilai parameter resistivitas dan ketebalan lapisan. Algoritma ini dipilih karena cepat menuju konvergen dan relatif stabil. $\mathrm{H}$ asil dari inversi ini diperoleh bahwa lapisan akuifer pertama berada pada kedalaman 21.4 - 52.1 meter dengan litologi batupasir berbutir halus dengan sisipan tufa Lapisan akuifer kedua berada pada kedalaman 52.170 meter dengan litologi breksi. Pada kedalaman $>70$ meter diinterpretasikan sebagai akuifer air tanah, namun memiliki debit yang kecil. Hal ini disebabkan karena litologi lapisan berupa breksi, dasit dan lava basal dari Formasi H ulusimpang. Sistem aliran air tanah pada lapisan ini merupakan sistem media pori yang berakibat pada debit rendah dan waktu pengisian kembali lapisan air tanah relatif lama.
\end{abstract}

Abstract. Gayau Village, which is located in Padang Cermin sub-district, Pesawaran, often experiences water dryness during the dry season so that it is necessary to carry out geoelectric measurements to identify the presence of groundwater aquifer layers. In this present study, the configuration used was the Schlumberger with M N / 2 stretch lengths of 1, 5, 10, and 20 meters. 
Gayau.Jurnal Geofisika Eksplorasi. M eanwhile, the length of the AB / 2 stretch is 6 to 300 meters. At the VES 07(02), 88-99.

(c) 2021 JGE (Jurnal Geofisika Eksplorasi). This article is an open-access article distributed under the terms and conditions of the Creative Commons Attribution (CC BY NC) data inversion stage, we used the Particle Swarm Optimization (PSO) algorithm to obtain the resistivity and layer thickness parameter values. This algorithm was chosen because it is fast to convergent and relatively stable. The results of this inversion show that the first aquifer layer located at depth of 21.4 - 52.1 meters with fine-grained sandstone lithology with tuff inserts. The second aquifer layer is at a depth of 52.1 - 70 meters with breccias lithology. At a depth of $>70$ meters it is interpreted as groundwater aquifer but has a small discharge. This is due to the lithology of thelayers in the form of breccias, dacites and basalt lava from the Hulusimpang formation. Where in this layer the groundwater flow system is a pore media system which results in low discharge and relatively long time to replenish the groundwater.

\section{PENDAHULUAN}

Kecamatan Padang Cermin, Kabupaten Pesawaran memiliki luas area sekitar $730 \mathrm{H} \mathrm{a} / \mathrm{m}^{2}$ dan terdiri atas 1722 penduduk. Banyaknya jumlah penduduk di desa tersebut juga meningkatkan kebutuhan konsumsi air bersih untuk kehidupan sehari-hari. Secara umum, rata-rata kedalaman sumur yang dimiliki oleh warga adalah $10 \mathrm{~m}$. Akan tetapi ketika musim kemarau tiba, sumur yang relatif dangkal tersebut menjadi kering sehingga warga sekitar menjadi kekurangan air bersih. Selain itu, pada saat musim hujan Desa Gayau sering dilanda banjir yang kemungkinan besar merupakan air limpahan karena secara geografis Desa Gayau berada di bawah pegunungan. Namun demikian, banjir tersebut tidak terjadi dalam waktu yang lama, hanya jika di puncak pegunungan hujan sehingga air menggenangi desa ini.

Pada bulan Desember tahun 2018, telah dilakukan pengeboran sumur hingga kedalaman sekitar $80 \mathrm{~m}$ namun tidak seperti yang diharapkan ketersediaan air dari sumur tersebut hanya bisa bertahan selama kurang dari satu bulan. Di samping itu, setelah dilakukan pengujian air oleh Dinas Kesehatan kualitas air tersebut tidak layak konsumsi. Di lain pihak, terdapat sumur warga yang mempunyai debit air relatif konstan dan terletak pada kedalaman sekitar $52 \mathrm{~m}$. Ke arah barat juga terdapat satu sumur warga dengan debit air yang cukup banyak pada kedalaman sekitar $30 \mathrm{~m}$. Meskipun memiliki debit yang relatif konstan, kedua sumur warga tersebut masih tercampur dengan pasir halus sehingga air yang diperoleh agak keruh kehitaman.

Dengan memperhatikan kondisi tersebut, maka perlu dilakukan survei metode geolistrik untuk mengindentifikasi keberadaan lapisan air tanah (akuifer) beserta kedalamannya sebelum pemboran guna meminimalisir kemungkinan mendapatkan sumur kering lagi. Selain itu juga perlu diketahui penyebab sumur bor milik Desa Gayau menjadi kering dan debitnya kecil padahal pemboran sumur cukup dalam mencapai 80 meter. Di sisi lain dengan tersedianya sumber air baik di permukaan ataupun didalam tanah akan mampu meningkatkan pembangunan di suatu daerah (Leggett dkk., 1984). M enurut Oseji dkk. (2005) menyatakan bahwa metode geolistrik mampu mendeteksi potensi keberadaan air di dalam tanah (akuifer) meskipun terdapat perbedaan kondisi geologi. Metode ini akan mendeteksi keberadaan lapisan air tanah berdasarkan parameter nilai resistivitas batuan.

Penggunaan metode geofisika untuk survei teknik dan lingkungan serta eksplorasi air tanah telah berkembang selama beberapa dekade tahun yang lalu seiring dengan kemajuan pengembangan aplikasi pengolahan data 
geofisika dan solusi numerik pemodelan geofisika. Metode VES telah tebukti menjadi metode yang sangat populer dalam eksplorasi air tanah (A dagunodo dkk., 2018; A raffa dkk., 2020; Mogaji \& Omobude, 2017; Mohamad dkk., 2017; Riska \& Satiawan, 2019) dan survei geoteknik lainnya dikarenakan metodenya yang sederhana dan mudah diaplikasikan serta biaya yang sangat terjangkau. Dari beberapa alasan yang diuraian tersebut, penelitian ini bertujuan guna memperkirakan keberadaan zona akuifer air tanah dengan menggunakan metode geolistrik VES dengan konfigurasi yang digunakan adalah Schlumberger guna membantu masyarakat Desa Gayau dalam mengetahui letak kedalaman lapisan akuifer air tanah.

\section{TINJAUAN PUSTAKA}

Pulau Sumatera berada pada zona subduksi aktif antara Lempeng Australia dan Lempeng Eurasia. Subduksi ini bergerak secara perlahan sejak zaman kapur dari arah timur laut menuju posisinya saat ini (Katili, 1975). Subduksi tersebut berlangsung secara miring sehingga menghasilkan Sesar Geser Sumatera yang merupakan sesar geser dekstral (Sieh \& N atawidjaja, 2000).

Zona sesar geser dekstral memiliki panjang $1650 \mathrm{~km}$ yang terbagi menjadi dua segmen utama yaitu segmen utara dan selatan. Segmen tersebut merupakan hasil dari perbedaan kecepatan subduksi pada Sumatera bagian utara dan selatan. Kecepatan pergerakan subduksi adalah $52 \mathrm{~mm} /$ tahun pada Sumatera bagian utara dan $60 \mathrm{~mm} /$ tahun pada Sumatera bagian selatan (Sieh \& Natawidjaja, 2000). A rea penelitian teletak pada segmen selatan yaitu di daerah Padang Cermin.

Secara geologi, Daerah Pesawaran tersusun oleh Formasi Lampung (QTI), alluvial (Qa), endapan vulkanik muda (Q hv), Formasi Sabu, (Tpos), Formasi Tarahan (Tpot), Formasi Menanga $(\mathrm{Km})$, Formasi Hulusimpang (Tomh), Kompleks Gunung Kasih yang tidak terkonsolidasi, Sekis Way Galih (Pzgs), Dasit Piabung, dan Granodiorit Dulan (Gambar 1).

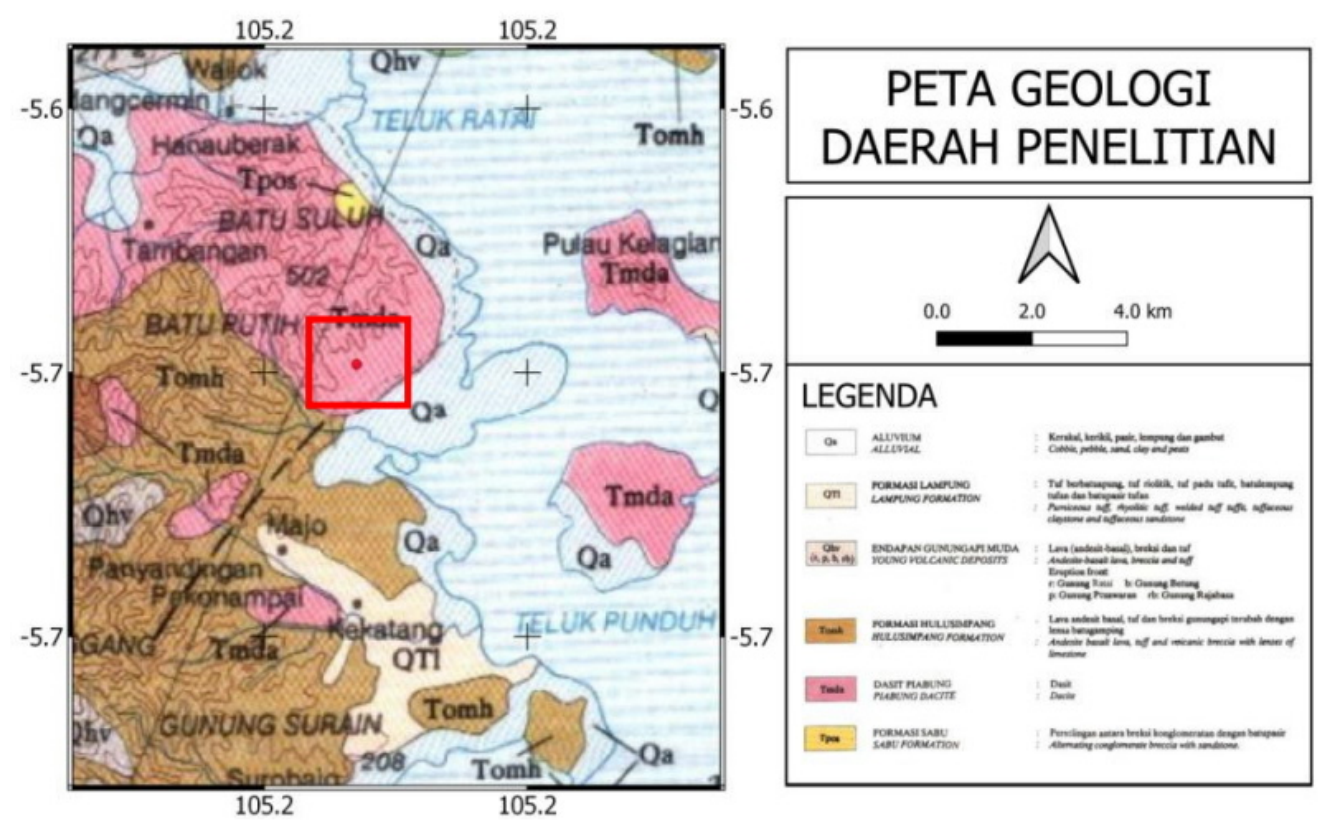

Gambar 1. Peta regional geologi pada daerah sekitar lokasi penelitian (dimodifikasi dari Mangga, 1993), dimana kotak merah merupakan lokasi penelitian. 
Stratigrafi area penelitian tersusun oleh batuan berumur Pre-Tersier, Tersier, dan Kuarter. Batuan Pre-Tersier merupakan batuan tertua yang terdiri atas batuan metamorf derajat rendah yaitu sekis, gneiss, marmer, kuarsit, termasuk kompleks Gunung Kasih. Disamping itu, terdapat Formasi $M$ enanga yang berumur Pra-Tersier Mesozoikum. Formasi tersebut tidak mengalami metamorfisme dan tersusun oleh batupasir tufan, batupasir karbonatan, rijang, dan basal

Batuan tersier tersusun oleh sekuen batuan busur vulkanik dan sedimen yang terendapkan secara ekstensif, meliputi Formasi Sabu, Campang, dan Tarahan. Ketiga formasi tersebut termasuk ke dalam umur Paleosen hingga Oligosen. Formasi Sabu terdiri atas batuan breksi-konglomeratan, batupasir, batulempung, dan batupasir tufan. Formasi Tarahan tersusun oleh batuan utama berupa tuff, breksi tuffan, dan andesit-basalt. Batuan utama Formasi Campang adalah batulumpur, shale, kalkarenit, breksi tuffan, dan konglomeratan. Disamping itu, batuan tersier lain berada pada Formasi Hulusimpang yang litologi berupa alkaline andesit-basal batugamping dan batuan andesit vulkanik yang terbentuk oleh proses subduksi didekat batas kontinen aktif (Mangga dkk., 1993). Batuan berumur Kuarter tersusun oleh lava Pleistosen, breksi, dan andesit-basal tufan.

\section{METODE PENELITIAN}

Pengukuran geolistrik VES ini dilakukan di Desa Gayau, Kecamatan Padang Cermin, Pesawaran, Lampung dengan jumlah titik pengukuran sebanyak 3 titik sounding ( Gambar 2). Pelaksanaan pengukuran dilakukan pada tanggal 28-29 Oktober 2020. Kami menggunakan konfigurasi Schlumberger dengan panjang bentangan $A B / 26$ hingga 300 meter. Sedangkan panjang bentangan $\mathrm{MN} / 2$ mulai dari 1, 5, 10 dan 20 meter.

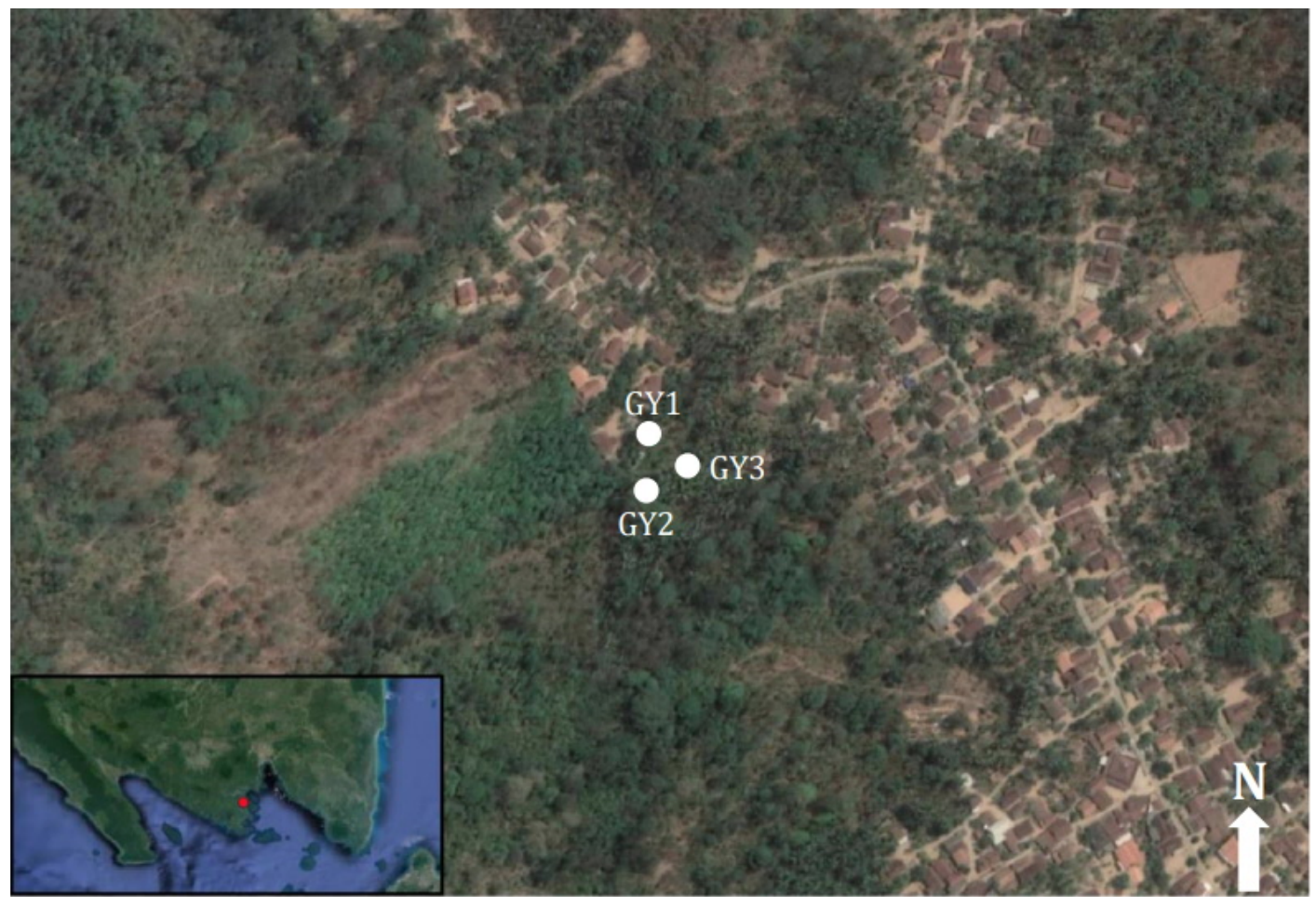

Gambar 2. Peta lokasi daerah penelitian di Desa Gayau. Titik warna putih merupakan titik pengukuran geolistrik dengan teknik VES konfigurasi schlumberger. 


\subsection{Vertical Electrical Sounding (VES)}

Pengukuran geolistrik dengan teknik VES bertujuan guna mendapatkan data variasi resistivitas batuan melalui pengukuran di suatu lokasi dengan merubah jarak spasi elektroda (Reynolds, 2005).

Dalam teknik Schlumberger, jarak pasangan elektroda potensial dianjurkan lebih kecil daripada jarak pasangan elektroda arus, yaitu jarak pasangan elektroda potensial $(\mathrm{MN} / 2)<$ 0,2 jarak pasangan elektroda arus (AB/2). Jarak $A B / 2$ yang lebih besar bertujuan untuk meningkatkan penetrasi kedalaman lapisan yang diperoleh. Jika terdapat perbedaan nilai potensial listrik yang sukar untuk diukur dan sensitivitas dari alat berkurang, maka jarak pasangan elektroda potensial ( $\mathrm{MN} / 2$ ) harus diperlebar (Telford dkk., 1990).

Dalam pengukuran geolistrik, parameter yang diperoleh adalah nilai resistivitas semu sebagai akibat dari model bumi yang berlapis. $\mathrm{N}$ ilai resistivitas semu dapat dihitung dengan menggunakan persamaan berikut:

$$
\rho_{a}=k \frac{\Delta V}{I}
$$

Dimana $\rho_{\alpha} \rho_{a}$ merupakan nilai resistivitas semu (ohm.m), $k$ adalah faktor geometri, $\Delta V$ adalah beda potensial yang terukur ( $\mathrm{mV}$ ), dan I adalah nilai arus yang terukur (mA). Untuk tiap-tiap konfigurasi memiliki nilai faktor geometri yang berbeda-beda. Besarnya nilai faktor geometri dalam konfigurasi schlumberger secara matematis dapat dihitung menggunakan persamaan dibawah ini:

$$
k=\pi\left(\frac{a^{2}-b^{2}}{2 b}\right)
$$

Dimana a merupakan jarak $A B / 2+M N / 2$ dan $b$ merupakan jarak M N/2.

Gambar $\mathbf{3}$ merupakan layout pengukuran metode geolistrik dengan menggunakan konfigurasi Schlumberger. Dalam prinsipnya, pengukuran dengan konfigurasi Sclumberger membuat jarak $P_{1} P_{2}$ menjadi lebih kecil dari pada jarak $\mathrm{C}_{1} \mathrm{C}_{2}$ tetapi karena terbatasan sensitivitas peralatan yang digunakan, sehingga saat jarak antara $\mathrm{C}_{1} \mathrm{C}_{2}$ semakin besar maka jarak antara $\mathrm{P}_{1} \mathrm{P}_{2}$ harus diperbesar.

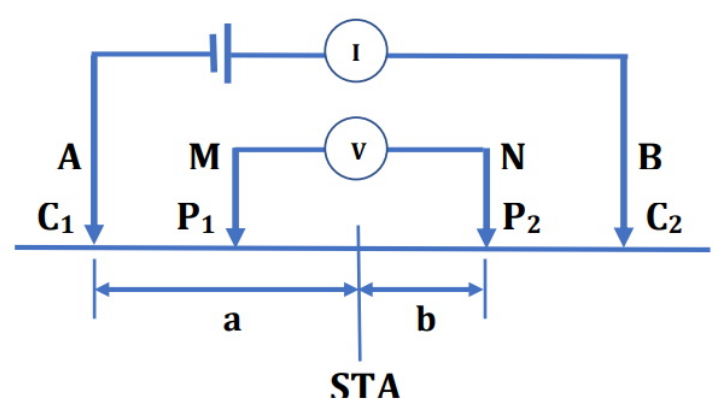

Gambar 3. Layout pengukuran metodegeolistrik dengan teknik VES konfigurasi Schlumberger (Riska \& Satiawan, 2019)

Selama pengukuran geolistrik di site pengukuran, quality control harus diperhatikan guna memperoleh kualitas data yang baik. Adapun beberapa hal yang dapat dilakukan selama pengukuran untuk memastikan data yang diperoleh sudah baik, yaitu (i) pastikan nilai kontak resistansi antara elektroda yang digunakan dan batuan yang diukur dengan peralatan yang dipakai harus bernilai rendah; (ii) selama proses pengukuran data dilapangan dianjurkan untuk membuat kurva resistivitas guna menghindari data yang kurang baik yang diakibatkan oleh kebocoran, atau efek samping selain pengukuran elektroda; (iii) mengubah letak elektroda atau melakukan pengukuran lebih dari sekali guna mencegah timbulnya distorsi atau error saat proses akuisisi; (iv) melakukan akuisisi yang overlap untuk nilai $\mathrm{AB} / 2$ (dengan $\mathrm{MN} / 2$ yang berbeda) dikarenakan nilai $\mathrm{MN} / 2$ yang berbeda dapat menimbulkan perubahan pada segmen kurva resistivitas (Riska \& Satiawan, 2019).

Selanjutnya jika data resistivitas sudah diperoleh, pengolahan data yang dilakukan adalah melakukan inversi data VES untuk mendapatkan nilai resistivitas yang sebenarnya dari tiap-tiap pelapisan bawah permukaan. 
Pada penelitian ini, teknik inversi yang dilakukan dengan menggunakan algoritma PSO. Dari inversi ini, parameter lain yang diperoleh selain nilai resistivitas sebenarnya adalah nilai ketebalan tiap-tiap lapisan.

\subsection{Particle Swarm Optimisation (PSO)}

PSO merupakan suatu teknik perhitungan yang mengadopsi prilaku sosial suatu kelompok burung (kawanan partikel) dalam menemukan makanan (Kennedy \& Eberhart, 1995). Ketika suatu individu memperoleh jalan terdekat ke arah targetnya maka individu yang lainnya dalam suatu kawanan akan bergerak atau mengikuti kearah jalan terpendek tersebut dan tiap-tiap individu akan mengingat posisi terbaik yang dilewatinya. Masing-masing individu akan membawa informasi yang berkaitan dengan kecepatan dan posisi dari target yang dinyatakan dalam vektor $\mathrm{V}$ (kecepatan) dan X (posisi). Kemudian tiap-tiap individu akan menyampaikan informasi kecepatan dan posisinya kepada individu yang lain dan setelah itu individu yang laun akan menyesuaikan kecepatan (V) dan posisi (X) berdasarkan informasi yang diterima.

Dalam inversi data VES, vektor posisi (X) berisi informasi parameter model $(\mathrm{m})$ yang diestimasi. Dalam hal ini, parameter model tersebut berupa ketebalan lapisan $(\mathrm{H})$ dan resistivitas sebenarnya $(\rho)$. Tahapan algoritma PSO adalah sebagai berikut:

a. Penentuan jumlah partikel dan iterasi yang akan digunakan dalam optimasi.

b. Membangkitkan populasi awal (X) dari rentang nilai pencarian model secara acak dan diperoleh populasi awal $X_{1}^{0}, X_{2}^{0}, X_{3}^{0}, \ldots, X_{j}^{i} ; i=$ iterasi $;$

$j=$ partikel $k e-n ; n=j u m l a h$

partikel. Untuk iterasi awal nilai $\mathrm{V}$ diset nol $\left(V_{1}^{0}=V_{2}^{0}=V_{3}^{0}=\cdots=V_{i}^{0}=0\right)$.

C. Evaluasi fungsi objektif dari tiap-tiap partikel yang dibangkitkan sehingga diperoleh nilai fungsi objektif $f\left[X_{1}^{0}\right] ; f\left[X_{2}^{0}\right] ; f\left[X_{3}^{0}\right] ; \ldots . . ; f\left[X_{j}^{0}\right]$. d. Penentuan parameter | dan g. I adalah parameter posisi (X) paling baik dari tiaptiap partikel dari total iterasi/perulangan yang dilakukan. Nilai g adalah posisi paling baik yang dapat ditempuh partikel dalam suatu kawanan. Indikator paling baik dapat diperhatikan pada nilai fungsi objektifnya, dimana posisi paling baik adalah saat nilai $f$ minimum.

e. Update nilai kecepatan (V) dan posisi (X) memakai algoritma PSO untuk tiap-tiap iterasi. Nilai $\mathrm{V}$ dan $\mathrm{X}$ dihitung dengan persamaan berikut:

$$
\begin{aligned}
& v_{i}(k+1)=\omega v_{i}(k)+\phi_{1}(g(k)- \\
& \left.x_{i}(k)\right)+\phi_{2}\left(l_{i}(k)-x_{i}(k)\right) \\
& x_{i}(k+1)=x_{i}(k)+v_{i}(k+1)
\end{aligned}
$$

dengan,

$$
\phi_{1}=r_{1} a_{g}, \phi_{2}=r_{2} a_{l}, r_{1}, r_{2}
$$

dimana $l_{i}(k)$ adalah posisi terbaik partikel ke-i, $g(k)$ adalah posisi global terbaik, $\omega$ adalah momen inersia, $\phi_{1}$ dan $\phi_{2}$ merupakan akselerasi global dan lokal, dan $a_{l}, a_{g}$ merupakan konstanta akselerasi lokal dan global. D engan menerapkan diskritisasi regresif (RR-PSO) pada kecepatan dan percepatan dalam fungsi waktu (Martínez \& Gonzalo, 2012), diperoleh model diskrit dengan persamaan sebagai berikut :

$$
\begin{aligned}
& x^{\prime}(t) \simeq \frac{x(t)-x(t-\Delta t)}{\Delta t} x^{\prime \prime}(t) \simeq \\
& \frac{x(t)-2 x(t-\Delta t)+x(t-2 \Delta t)}{\Delta t^{2}}=\frac{x^{\prime}(t)-x^{\prime}(t-\Delta t)}{\Delta t}
\end{aligned}
$$

Maka persamaan untuk RR-PSO secara matematis dapat dituliskan sebagai berikut:

$$
\begin{aligned}
& v(t-\Delta t)= \\
& \frac{v(t)+\phi_{1} \Delta t(g(t)-x(t))+\phi_{2} \Delta t(l(t)-x(t))}{1+(1-\omega) \Delta t+\phi \Delta t^{2}} x(t+ \\
& \Delta t)=x(t)+v(t+ \\
& \Delta t) \Delta t ; \quad t, \Delta t \in \mathbb{R} x(0)=x_{0} ; \\
& v(0)=v_{0} ; \phi=\phi_{1}+\phi_{2}
\end{aligned}
$$

Dalam melakukan inversi PSO, penentuan nilai tunning parameter ini sangat penting untuk mendapatkan hasil yang terbaik. Nilai 
tunning parameter yang kami gunakan merujuk pada (Laby dkk., 2016; Martínez dkk., 2010) dengan $\omega=0.8, \quad a_{l}=1.8$ dan $a_{g}=2$. Selanjutnya pada tahapan inversi kami membangkitkan jumlah partikel sebanyak 500 dengan iterasi sebesar 100 kali pengulangan. Secara teori, dengan semakin banyaknya jumlah partikel dan jumlah iterasi yang dipakai, maka model yang dihasilkan akan semakin akurat. Namun dengan jumlah yang banyak, akan mengakibatkan waktu komputasi yang lebih lama.

\section{HASIL DAN PEMBAHASAN}

Gambar 4 menunjukkan kurva resistivitas hasil pengukuran (warna biru) dan kurva resistivitas hasil inversi (warna merah) dengan menggunakan algoritma PSO. Dari hasil inversi tersebut, secara keseluruhan algoritma PSO mampu menghasilkan kurva resistivitas kalkulasi yang relatif sama dengan kurva resistivitas observasi. Kemiripan ini ditandai dengan nilai RM S error yang kecil (Gambar 6). Pada titik GY1 mempunyai nilai RMS error sebesar 2.55\%, sedangkan pada titik GY2 mempunyai nilai RMS error sebesar $6.76 \%$ dan pada titik GY3 mempunyai nilai RMS error sebesar $4.16 \%$. Kurva nilai error hasil inversi dapat dilihat pada Gambar 6 yang menggambarkan bahwa algoritma PSO cepat menuju konvergen dan relatif stabil. Pada iterasi ke-20 untuk semua titik pengukuran telah menuju ke model yang sama (konvergen) hingga iterasi ke-100. Hal ini sesuai dengan hasil penelitian dari Laby dkk., (2016) dan Ding dkk. (2019) yang menunjukkan bahwa PSO lebih cepat menuju konvergen dengan error yang kecil.

M odel profil resistivitas terhadap kedalaman hasil inversi dengan menggunakan algoritma PSO dapat dilihat pada Gambar 5. Pada tahapan inversi ini kami membuat model sebanyak 4 lapisan ditambah dengan 1 lapisan yang merupakan lapisan half-space. Sedangkan batasan ruang pencarian model untuk tiap-tiap lapisan kami batasi dengan nilai resistivitas minimum sebesar 1 ohm.m dan resistivitas maksimum sebesar 500 ohm.m. Parameter ketebalan $(\mathrm{H})$ lapisan kami batasi dengan nilai $\mathrm{H}$ minimum sebesar 1 meter dan maksimum sebesar 40 meter. Dari hasil inversi yang diperoleh, untuk semua titik pengukuran, mampu mencakup kedalaman rata-rata hingga 75 meter untuk 4 lapisan awal. Sedangkan untuk lapisan half-space diperoleh nilai resistivitas yang relatif stabil untuk semua titik pengukuran.

Tabe 1 adalah hasil interpretasi litologi lapisan tanah yang mengacu pada geologi daerah sekitar dan merujuk pada hasil penelitian dari Riska dan Satiawan (2019). Lapisan 1 dengan kedalaman rata-rata 0-12 meter berpotensi menjadi akuifer air tanah dengan litologi berupa tanah dengan perselingan aluvial dan tuff. Pada lapisan ini merupakan akuifer bebas dimana muka air tanah akan naik ketika musim hujan dan akan turun ketika musim kemarau. Pada daerah penelitian, lapisan 1 ini sangat dirasakan oleh warga ketika terjadi musim kemarau. Daerah sekitar akan mengalami kekeringan dan sulit air. 

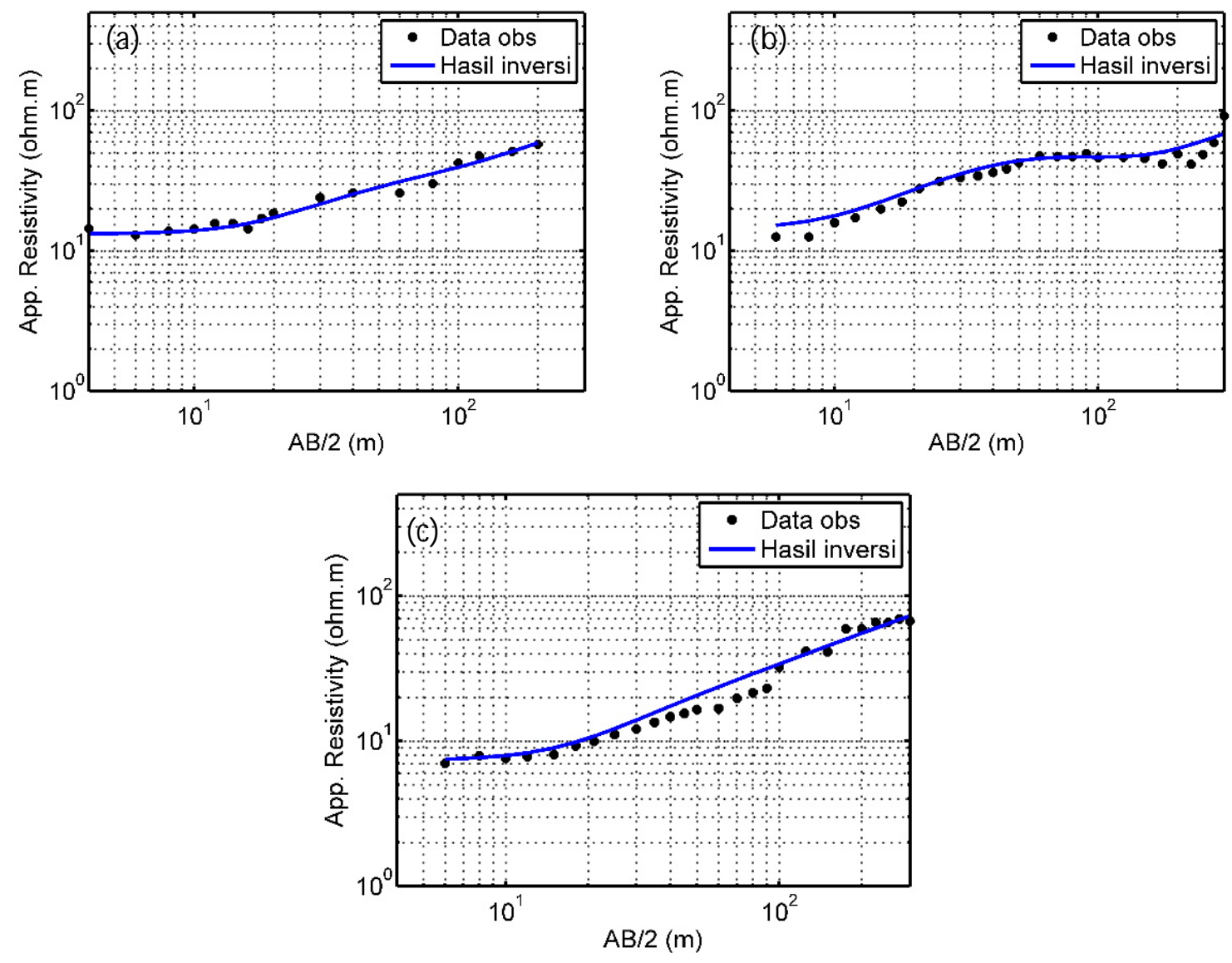

Gambar 4. Kurva resistivitas hasil observasi (warna biru) dan kurva resistivitas hasil kalkulasi (warna merah); (a) titik GY 1; (b) titik GY2; (c) titik GY3.

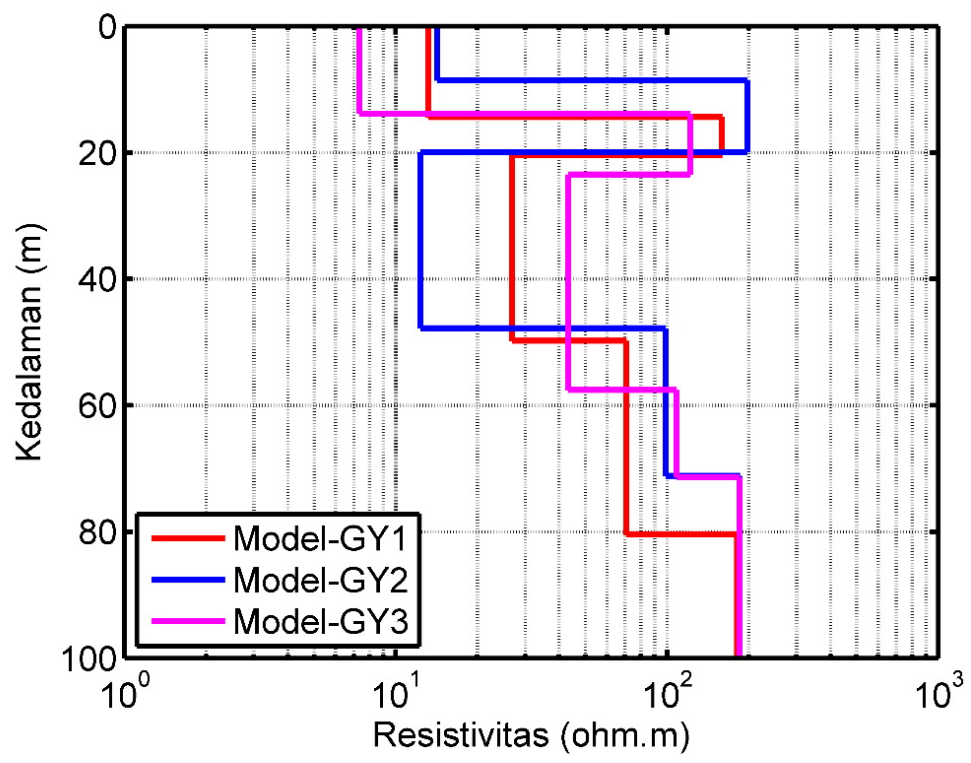

Gambar 5. Profil resistivitas terhadap kedalaman hasil inversi. 


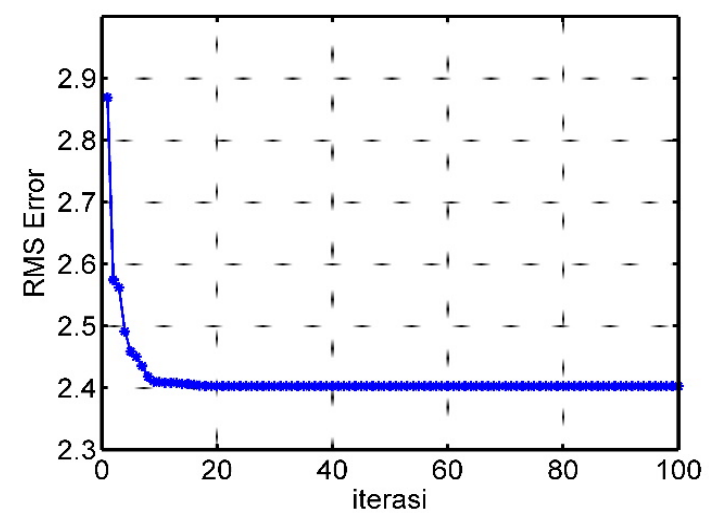

(a)

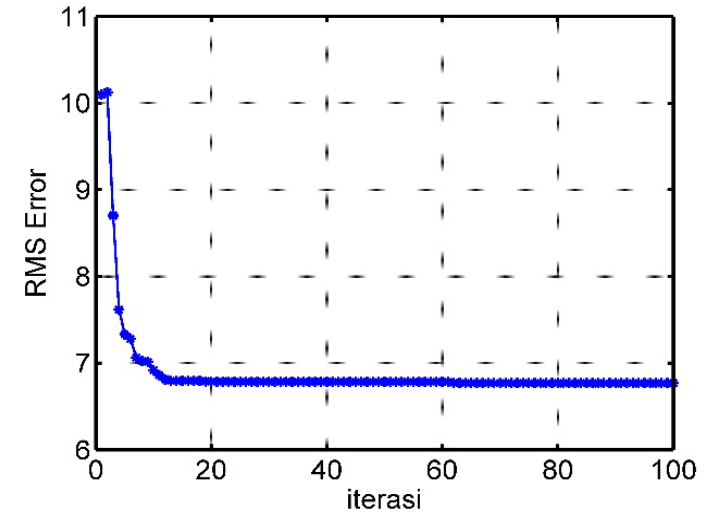

(b)

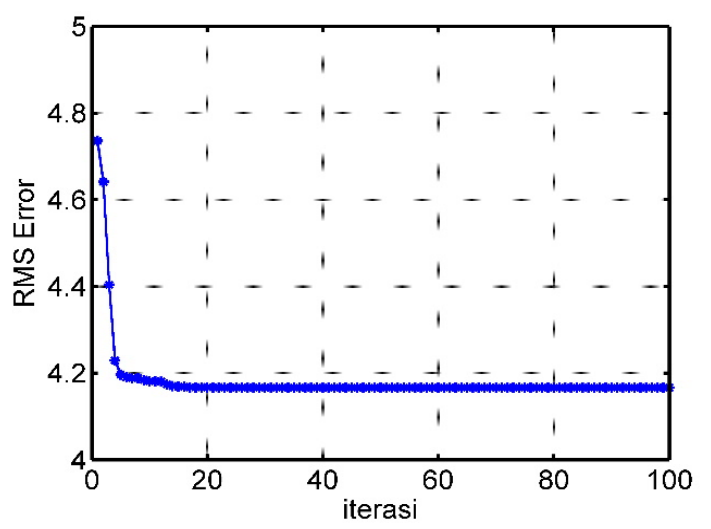

(c)

Gambar 6. Kurva error hasil inversi dengan menggunakan algoritma PSO; (a) Titik GY 1; (b) titik GY2; (c) titik GY3.

Tabel 1. Interpretasi litologi bawah permukaan berdasarkan data resistivitas dan ketebalan lapisan hasil inversi.

\begin{tabular}{|c|c|c|c|c|c|c|c|}
\hline \multirow[b]{2}{*}{ Lapisan } & \multicolumn{2}{|c|}{ Titik GY1 } & \multicolumn{2}{|c|}{ Titik GY2 } & \multicolumn{2}{|c|}{ Titik GY3 } & \multirow[b]{2}{*}{ Litologi } \\
\hline & $\begin{array}{c}\text { Rho } \\
\text { (ohm.m) }\end{array}$ & $\begin{array}{c}\mathrm{H} \\
(\mathrm{m})\end{array}$ & $\begin{array}{c}\text { Rho } \\
\text { (ohm.m) }\end{array}$ & $\begin{array}{l}\mathrm{H} \\
(\mathrm{m})\end{array}$ & $\begin{array}{c}\text { Rho } \\
\text { (ohm.m) }\end{array}$ & $\begin{array}{c}H \\
(\mathrm{~m})\end{array}$ & \\
\hline 1 & 12.53 & 13.57 & 14.26 & 8.61 & 7.36 & 13.88 & $\begin{array}{l}\text { Tanah dengan } \\
\text { perselingan } \\
\text { tuff dan alufial } \\
\text { (akuifer). }\end{array}$ \\
\hline 2 & 165.59 & 7.29 & 197.64 & 11.36 & 121.71 & 9.59 & $\begin{array}{l}\text { Lapisan keras } \\
\text { hasil gunung } \\
\text { api muda } \\
\text { (diperkirakan } \\
\text { dasit dan lava } \\
\text { basalt). }\end{array}$ \\
\hline 3 & 22.35 & 30.29 & 12.31 & 27.80 & 43.28 & 34.11 & $\begin{array}{c}\text { Batupasir } \\
\text { berbutir halus } \\
\text { dengan sisipan }\end{array}$ \\
\hline
\end{tabular}




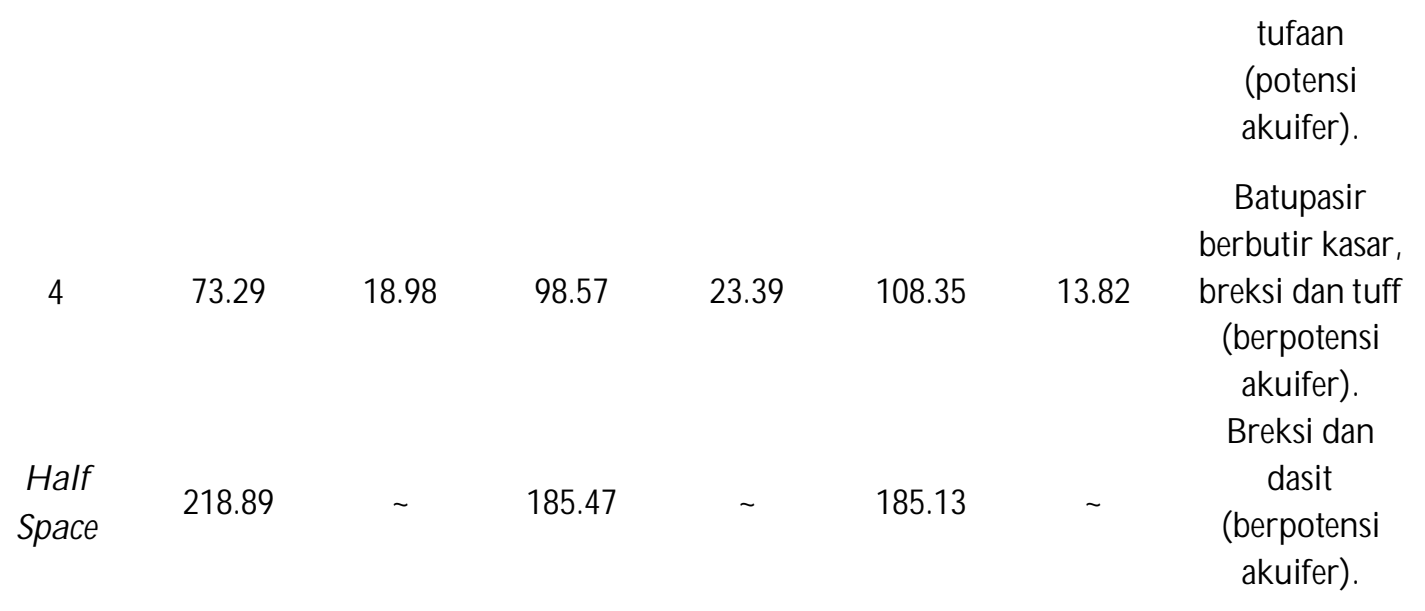

Pada lapisan 2 merupakan aquitard/ aquiklud yang menjadi lapisan penahan air dari lapisan atas dan bawahnya dengan litologi berupalapisan batuan keras (diperkirakan dasit Piabung dan lava basalt dari formasi Hulusimpang). Lapisan ke-2 ini terletak di kedalaman 12-21.4 meter dengan ketebalan 9.4 meter. Lapisan selanjutnya merupakan lapisan akuifer air tanah dengan litologi batu pasir berbutir halus dan sedikit sisipan tuff. Ketebalan lapisan ini mencapai 30.7 meter dan terdapat di kedalaman 21.4-52.1 meter. Pada lokasi sekitar daerah penelitian, di kedalaman ini mempunyai debit air yang konstan, namun butiran pasir dari lapisan batupasir berbutir halus dapat terangkat saat dilakukan penyedotan air oleh mesin pompa air.

Lapisan ke-4 diidentifikasi sebagai akuifer yang mempunyai potensi akuifer yang sama dengan lapisan ke-3. Yang membedakan keduanya adalah adanya sisipan pada lapisan batuannya. $\mathrm{Hal}$ ini dibuktikan dengan adanya perbedaan nilai resistivitas batuan. Perbedaan nilai resistivitas batuan ini dikarenakan adanya sisipan breksi. Lapisan ini mempunyai ketebalan 18.7 meter dan terdapat di kedalaman 52.4 - 70 meter.

Selanjutnya pada lapisan paling bawah (lapisan 5) yang terletak pada kedalaman $>70$ meter merupakan lapisan yang masih berpotensi menjadi akuifer. Hal ini dibuktikan dengan adanya sumur bor warga hingga kedalaman 80 meter yang menunjukkan adanya air tanah. Namun lapisan ini tidak memiliki debit yang konstan atau kecil. Hal ini dikarenakan lapisan ke 5 tersusun oleh litologi berupa breksi dengan perselingan dasit Piabung dan lava basat. Lapisan ini dapat menjadi lapisan akuifer air tanah, namun akan mempunyai debit yang kecil dikarenakan sistem aliran air tanah menggunakan sistem media pori.

\section{KESIMPULAN}

Berdasarkan hasil penelitian metode inversi PSO pada data geolistrik dengan teknik VES di daerah Gayau memberikan hasil bahwa algoritma inversi PSO cepat menuju konvergen dan relatif stabil. Algoritma ini tidak membutuhkan iterasi yang panjang untuk menuju ke nilai error yang relatif lebih kecil.

Selanjutnya yang menjadi penyebab sumur bor Desa Gayau menjadi kering atau debitnya berkurang dikarenakan kedalaman sumur bor berada di litologi batuan yang relatif lebih keras dari formasi Hulusimpang. Dimana pada lapisan ini sistem aliran air tanahnya merupakan sistem media pori yang berakibat pada debit yang rendah dan waktu pengisian kembali lapisan air tanah di lapisan ini relatif lama.

Lapisan akuifer pertama berada pada kedalaman 21.4-52.1 meter dengan litologi batupasir berbutir halus dengan sisipan tuff. Namun pada kedalaman ini dimungkinkan 
butiran pasir dapat terangkat saat dilakukan penyedotan air ke tangki penampungan air. Sedangkan lapisan akuifer kedua berada pada kedalaman 52.1-70 meter dengan litologi breksi/batupasir berbutir kasar.

\section{UCAPAN TERIMA KASIH}

U capan terima kasih kami sampaikan kepada Lembaga Penelitian, Pengabdian Masyarakat, dan Penjaminan Mutu Institut Teknologi Sumatera atas skema hibah friendly yang telah diberikan dengan no kontrak B/8600/IT 9.C1/PM .01.01/2020. Kami juga berterima kasih kepada Aparatur dan warga Desa Gayau yang telah berkontribusi dalam pelaksanaan penelitian ini.

\section{DAFTAR PUSTAKA}

Bogdonoff, S., \& Rubin, J. (2007). The regional greenhouse gas initiative: Taking action in Maine. Environment, 49(2), 9-16.

Gore, A. (2006). An inconvenient truth: The planetary emergency of global warming and what we can do about it. Emmaus, PA: Rodale.

M ichaels, P. J., \& Balling, R. C., Jr. (2000). The satanic gases: Clearing the air about global warming. Washington, DC: Cato Institute.

M ora, C., \& M aya, M. F. (2006). Effect of the rate of temperature increase of the dynamic method on the heat tolerance of fishes. Journal of Thermal Biology, 31, 337-341. doi: 10.101b/jtherbio.2006.01.055

A dagunodo, T. A., A kinloye, M. K., Sunmonu, L. A., Aizebeokhai, A. P., Oyeyemi, K. D., \& Abodunrin, F. O. (2018). Groundwater Exploration in Aaba Residential Area of A kure, Nigeria. Frontiers in Earth Science, 6, 66. https://doi.org/10.3389/feart.2018.00066

A raffa, S. A. S., Alrefaee, H. A., \& N agy, M. (2020). Potential of groundwater occurrence using geoelectrical and magnetic data: A case study from south Wadi Hagul area, the northern part of the Eastern Desert, Egypt. Journal of African Earth Sciences, 172, 103970. https://doi.org/10.1016/j.jafrearsci.2020.103970

Ding, Y., Zhang, W., Yu, L., \& Lu, K. (2019). The accuracy and efficiency of GA and PSO optimization schemes on estimating reaction kinetic parameters of biomass pyrolysis. Energy, Elsevier, 176(C, 582-588.

Katili, J. A. (1975). Evolution of the Southeast Asian Arc Complex. J. Indon. Assoc. Geol.

Kennedy, J., \& Eberhart, R. (1995). Particle swarm optimization. Proceedings of ICNN'95 International Conference on Neural Networks, 4, 1942-1948 vol.4. https://doi.org/10.1109/ICN N.1995.488968

Laby, D. A., Sungkono, Santosa, B. J., \& Bahri, A. S. (2016). RR-PSO: Fast and Robust Algorithm to Invert Rayleigh Waves Dispersion. Contemporary Engineering Sciences, 9, 735-741.

Leggett, W. C., Frank, K. T., \& Carscadden, J. E. (1984). Meteorological and Hydrographic Regulation of Year-Class Strength in Capelin (M allotus villosus). Canadian Journal of Fisheries and Aquatic Sciences, 41(8), 1193-1201. https://doi.org/10.1139/f84-141

M angga, S. A., Amirudin, Suwarti, T., Gafoer, S., \& Sidarto. (1993). Peta Geologi Lembar Tanjung Karang, Sumatera.

M artínez, J. L. ., García Gonzalo, E., Álvarez, J. P. F., Kuzma, H. A., \& Pérez, C. O. M . (2010). PSO: A Powerful Algorithm to Solve Geophysical Inverse Problems Application to A 1D-DC Resistivity Case. Journal of Applied Geophysics, 71, 13-25.

M artínez, J. L. ., \& Gonzalo, E. . (2012). Stochastic Stability and Numerical Analysis of Two Novel Algorithms of The PSO Family: PP-GPSO and RR-GPSO. International Journal on Artificial Intelligence Tools, 21(3).

M ogaji, K. A., \& Omobude, O. B. (2017). M odeling of geoelectric parameters for assessing groundwater potentiality in a multifaceted geologic terrain, I pinsa Southwest, Nigeria - A GIS-based GODT approach. NRIAG Journal of Astronomy and Geophysics, 6(2), 434-451. https://doi.org/https://doi.org/10.1016/j.nrjag.2 017.07.001

M ohamad, F., M ardiana, U., Yuniardi, Y., N ur, A. A., \& Alfadli, M. K. (2017). Potensi Akuifer Kampus A rjasari Berdasarkan Pengamatan Nilai Tahan Jenis Batuan. Bulletin of Scientific Contribution: GEOLOGY 15 (2), 129-138.

Oseji, J. O., Atakpo, E. A., \& Okolie, E. C. (2005). Geoelectric Investigation of The Aquifer Characteristics and Groundwater Potential in 
Kwale, Delta state, Nigeria. Journal of Applied Sciences \& Environmental M anagement, 9, 157160.

Reynolds, J. M. (2005). Principles of Applied Geophysics. Cambridge University Press.

Riska, \& Satiawan, S. (2019). Inverstigasi Lapisan Akuifer Berdasarkan Data Vertical Electrical Sounding (VES) dan Data Electrical Logging: Studi Kasus Kampus Itera. Bulletin of Scientific Contribution: GEOLOGY, 17(2), 91-100.
Sieh, K., \& Natawidjaja, D. (2000). N eotectonics of the Sumatran fault, Indonesia. Journal of Geophysical Research: Solid Earth, 105, 2829528326.

Telford, W . M., Geldart, L. P., \& Sheriff, R. E. (1990). Applied Geophysics (2nd ed.). Cambridge University

Press. https://doi.org/10.1017/CB09781139167932 